\title{
Introduction: In Search of Economic Policies to Stabilise Democratic Transitions
}

\author{
Giacomo Luciani
}

\begin{abstract}
Democratic transitions in the Middle East and North Africa have mostly failed to consolidate and have been hindered by the difficult economic heritage of previous authoritarian governments. Yet newly established democratic governments must deliver on the expectations of their people, especially the poorer strata, otherwise disillusionment may open the door to restoration of authoritarian rule. The introductory chapter reviews existing literature on the topic and presents the contributions of the collective volume to this crucially important discussion. Can democracy succeed? Various ideas for economic policies that may help consolidate the democratisation process are proposed, while major obstacles on the way to democratic success are also highlighted.
\end{abstract}

\section{Introduction}

With the solitary exception of Tunisia, where a still fragile process of democratic consolidation appears to be making progress in the face of multiple challenges, the Arab Spring has led to either a restoration of authoritarian rule (in Egypt, and in Bahrain and the other members of the Gulf Cooperation Council (GCC)) or civil war (in Iraq, Syria, Libya and Yemen).

This state of affairs is obviously unsettling. For decades the political economy debate about the Middle East and North Africa (MENA) has focused on the causes and negative consequences of authoritarianism, and has preached democratic good governance, promising instantaneous and almost unconditionally improved growth and integration into the globalisation process (Acemoglu et al., 2014; World Bank 2016). Then an opportunity for transition to democracy arises-largely unexpected and certainly unpredicted-and almost universally fails. Unavoidable questions then confront us: is democracy possible? Is it desirable? How can we increase the chances for newly established democratic governments to deliver and consolidate?

The Arab Spring has encouraged a broad debate concerning its causes; less so about how it might develop. Much of the literature has focused on ideology, 
identity and longing for human dignity (Achcar, 2013; Hanieh, 2013; Kamrava, 2014; Selvik and Utvik, 2016). The analysis has mostly been conducted at the level of individual countries; the regional dimension of the phenomenon has generally not been recognised and explained. Economic causes of discontent are frequently mentioned, but are rarely supported by empirical data (notable exceptions are Alvaredo and Piketty, 2014; Azmeh, 2014; Beinin, 2016; Hakimian, 2013a and 2013b; Luciani, 2016; Nugent, 2012; and Verme et al., 2014).

It is of course necessary to form a better understanding of the causes and meaning of the Arab Spring in order to meaningfully discuss its eventual failure. That said, the focus of this collection is not on the causes, but on the dilemmas that governments in power, whether incumbent or issuing from a democratic transition, must face in addressing the unresolved underlying issues that led to the revolt. Important recent contributions that have addressed in a similar manner the issue of post-revolution economic policies include, notably, works of Magdi Amin et al. (2012), Hafez Ghanem (2016a), Schiffbauer et al. (2015), and the World Bank (2014).

What needs to be done to deliver the minimum improvement in living conditions that will convince the people that indeed things are changing for the better? Can a democratic government implement the measures necessary? Or do we still need a degree of authoritarianism before a successful democratic transition is conceivable? What can the democratic world do to support the consolidation of democratic transitions? Or should democratic countries accept that an authoritarian parenthesis is inevitable and keep searching for the oxymoron: a democratising authoritarian government?

For Europe at least, these are not just academic questions. The civil wars, restorations of authoritarian rule, and developmental failures in the Middle East and North Africa have led to an unprecedented wave of refugees and economic migrants that the European Union and other European countries are unable to deal with. Faced with a humanitarian crisis of biblical proportions, Europe is falling apart, turning into not one, but multiple fortresses. It is a political return to the Middle Ages, where localism and defence against encroachment from outside are the leading values.

If democracy is to be saved, it has to be saved everywhere. In a globalised world, it is simply impossible to be indifferent to the fate of neighbouring countries. The European Union (EU) has long had a concept of its 'neighbourhood' and formulated policies - on paper at least - to support the respect of human rights, and good governance and democracy. The fact is that policies adopted so far have accomplished nothing, and have almost exclusively been disasters. In its latest revision the European Neighbourhood Policy appears to have abandoned any ambition to foster democratisation (Schuhmacher, 2016). Is there anything that could be done better? Are we following the right recipes? 
We badly need to engage in this debate, and academics have a moral duty to put their minds to it.

\section{The Economic Heritage of Authoritarianism}

At least since the turn of the millennium, if not earlier, Arab authoritarian governments have come to terms with the 'Washington Consensus', with variable degrees of enthusiasm. They have pursued policies of fiscal stabilisation, which progressively allowed typical features of the past-such as high inflation, capital controls, trade protectionism and multiple exchange rates - to be overcome. Economies were opened and active participation in the globalisation process was sought. International specialisation in goods and services for which the countries could claim comparative advantage was accepted, which resulted in less emphasis on industry and subsistence agriculture, more on export agriculture (Woertz, this volume) and export services such as, principally, tourism.

Generally, these developments were lauded by international financial organisations. It was expected that the Arab economies would be able to attract increased foreign direct investment, which would have led to accelerated growth, improved productivity and competitiveness, and the creation of jobs in line with population growth and the youth bulge (Fargues, this volume). The outcome of these policies was partially, yet not entirely disappointing.

Things have also been problematic from the point of view of democratic transition. Capital-intensive investment in mining and industry displays strong resistance to political disturbances, because the large amount of sunk capital encourages resilience, plus generally projects are remote from densely inhabited centres and are not as vulnerable as sometimes believed. It is therefore generally the case that such investment may be slowed down but not reversed; nor is production interrupted should political instability occur, except in extreme cases where the security of company personnel is directly threatened. In contrast, financial investment and tourism are extremely vulnerable to political instability, and this is the other side of the democratic transition coin. As soon as the incumbent authoritarian regime collapses, foreign investment will stop coming in, domestic and foreign money will tend to flow out, and international rating agencies will revise the country's rating downwards. This immediately creates a negative spiral, which a newly elected democratic government (or, more likely, a provisional government lacking full democratic legitimation and with a very uncertain life expectancy) will find difficult to reverse.

Tourism is also extremely vulnerable to political disturbances and uncertainty. The vast majority of potential tourists are not interested in witnessing 
a revolution. In the time that popular uprisings will take to provoke the fall of the authoritarian regime, the tourist trade will quickly dry up. Once a democratic transition is underway, tourists will still normally want to be reassured that conditions are stable and security is guaranteed; recovery will be gradual. This means that a newly elected democratic government is likely to be confronted with rapidly deteriorating economic conditions in the tourism sector, depending on the importance of that sector in the national economy. Furthermore, even once the democratic transition is well underway, it is not difficult for opponents or extremists to stage terrorist attacks targeting tourists, which will have the immediate effect of precipitating a new crisis or extending the existing one. The damaging economic impact of terrorism is evident and feared even in Europe or the United States, but much more so in MENA, including in such primary tourist destinations as Egypt, Tunisia or Morocco. ${ }^{1}$

Tourism is also a labour-intensive sector, which supports local agriculture, handicrafts and small-scale commercial activities. A sudden downturn in tourist activity is likely to be immediately felt by a significant share of the population, mostly from relatively low-income or poorer strata.

With respect to fiscal policy, authoritarian regimes have pursued balanced budgets primarily by cutting down on social services (generally by simply not increasing expenditure in line with population growth, and letting quality progressively deteriorate). Such regimes have, however, tended to maintain and in some cases even expand entitlements in the form of subsidised or exceedingly low prices for selected necessities (primarily basic food items) and energy products (oil products, gas and electricity). The latter have mainly a regressive impact on income distribution (as documented by El-Katiri and Fattouh, and Hertog - both in this volume) while the former are more benign (as explained by Woertz and, in the case of Egypt, by Springborg, both in this volume). Nevertheless, it is energy subsidies that have come to absorb an exceedingly important share of government budgets, in part because the price of oil increased rapidly between 2003 and 2008 and remained very high subsequently. Newly empowered democratic governments were therefore immediately confronted with the challenge of announcing unpopular measures while their legitimacy and hold on power was still quite shaky.

Notwithstanding evident weaknesses, the economic growth record of the authoritarian regimes over the 2000-10 decade was not altogether negative

1 In Egypt, international tourism revenue in 2015 totalled USD 6.1 billion, while in 2010 it had stood at USD 12.5 billion. In Tunisia tourist revenue peaked in 2008, was down by roughly one-third by 2013, and further declined in 2015 following terrorist attacks on tourist facilities. See also World Bank (2016). 
(Amin et al., 2012; Ghanem, 2016a; Hakimian, 2013a and 2013b; Devarajan and Mottaghi, 2014). Arab countries, and not just the major oil exporters, experienced a decade (or more) of rapid growth up to 2010; growth suffered subsequently because of the negative impact of the Spring, especially on certain sectors. However, this growth did not benefit all equally: although most measurements of income distribution do not show increasing concentration (Hakimian, 2013b), employment opportunities for young people (especially if educated) worsened significantly. Ghanem (2016a) also points to unemployment among educated young entrants to the job market, but also to the worsening or stagnating conditions in marginalised regions (e.g. Upper Egypt) or sectors (e.g. agriculture). Finally, Alvaredo and Piketty (2014) convincingly argue that data sources that are currently available at the national level in Egypt or other MENA countries are insufficient to derive reliable estimates of top income shares, and that income inequality is extremely large at the level of the Middle East region taken as whole. It is the perception of such growing inequality, further fuelled by the growing role of regional media and the constant image of Dubai-style success that they project, that ignited the resentment and revolt against incumbent authoritarian regimes. The widening gap in incomes and wealth at the regional level is the key target of popular revolt: democracy must succeed in bringing about a reversal of this trend. ${ }^{2}$

\section{3} Well-Established Recipes Do Not Support Democratic Transitions

Faced with a declining economy, falling government revenues and excessive expenditure on subsidies, governments issuing from the demise of authoritarian regimes were encouraged to persist in the policies of the Washington Consensus - that is, primarily cutting outlays by reducing subsidies and other expenditure, privatising government-owned enterprises, and improving tax collection.

Such policies promise immediate political costs but deferred advantageshardly the ideal path for a democratic government in need of consensus and consolidation. True, democratic legitimation is necessary if one is to pursue controversial or unpopular policies, but democracy needs to be well rooted for that. A country undergoing democratic transition needs both a high degree of consensus to establish a national pact that will underpin a new constitution,

2 After the revolt, the Arab Barometer conducted a survey asking Tunisians what was the main reason for their revolt. More than 60 per cent of respondents indicated a 'weak economy' was their main motivation. (Cited in Ghanem, 2016a). 
and compromises among a broad spectrum of political forces. This does not bode well for potentially unpopular measures.

Revolt against incumbent authoritarian regimes certainly is motivated largely by a desire for freedom, for respect for human rights, and for dignity; but the poorer strata of the population also expect an improvement in their material conditions - at least some sign that income distribution may be moving in the right direction. Traditional macroeconomic stabilisation policies go in the opposite direction.

In fact, evidence of growing income inequality everywhere in the world, in advanced as well as in emerging countries, points to the conclusion that the globalisation process has supported a greater concentration of income and wealth rather than the opposite. Thus, while reverting to greater isolation from the global economic environment is not an option for any country, and certainly not for a country pursuing democratisation, the rules of globalisation are not helpful (Springborg 2016).

The debate on income inequality has greatly intensified among economists since the turn of the century with reference to all countries, not just to the MENA region (Piketty, 2013; Atkinson, 2015). It has become evident that the process of globalisation has had profound consequences for the distribution of income in industrial and in emerging countries, leading to a greater concentration of income and wealth at the global level. In mature democracies, this trend is viewed as a potential threat to the satisfactory functioning and stability of institutions, but little attention has been paid to the consequences that it might have on democratisation processes. The standard line is that concentration of income and wealth may lead to growing dissatisfaction and eventually revolt: but in the initial stages of democratic transition, the limited opportunities to implement redistributive policies may endanger the process itself.

At the heart of the problem is increased international competition, which has led to deindustrialisation and the weakening of labour movements in all countries where industry and trade unions used to be important players. ${ }^{3}$ The liberalisation of international trade and capital movements has brought about a radical change in the labour/capital bargaining balance. While some minority voices advocate a reversal of the globalisation process and a return

3 Beinin (2016) insists on the importance of the role of trade unions and labour activism in Egypt and Tunisia. In the case of the latter country, trade unions also plaid a significant political role in the transition process in the context of the so-called Quartet. Nevertheless, formal employment in both countries remains limited, and in the rest of the region trade unions are hardly a significant force. 
to greater national control over the economy to protect a broad range of welfare and rights-related legislation, it is unlikely that the world will go back to protectionism.

The more sophisticated discussion of inequality in a globalised context seeks ways of mitigating the trend towards growing concentrations of income and wealth by considering measures that are compatible with freedom of trade and capital movements. In this context, the role of education and of progressive taxation on income and wealth are frequently cited as the appropriate solutions-although fiscal competition constitutes a grave threat to the ability of individual states, even in the European context, to manage or tighten their taxation systems.

Almost all redistributive policies are administratively complex and require time to implement and even more time to show their effects. This means that they are not adapted to conditions prevailing in countries that are undergoing a democratic transition. We therefore face a potential vicious circle: if strong and accountable institutions are needed for successful participation in the globalisation process, but the latter worsens income and wealth inequality, which constitutes a powerful obstacle to democratic transitions, then countries with weak/unaccountable institutions are condemned to economic marginalisation and to having inferior institutions.

\section{4}

\section{The Quest for Alternatives}

It is this critical nexus that the chapters in this book explore from different angles. The broad question is: what economic policies and development priorities should be pursued by governments in the early phases of democratic transition processes? As mentioned already, the literature addressing this question so far has been limited.

Both of the major contributions to the literature originate from collective efforts undertaken under the aegis of the Brookings Institution. The first project took place in 2011 and led to the publication of a volume by Magdi Amin et al. (2012). The second took place five years after the eruption of the Spring (as is self-evident from the title The Arab Spring Five Years Later) and led to the publication of two volumes, one entirely written by Hafez Ghanem (2016a) and the other edited by the same (2016b).

The first book sets off from premises that are very similar to our own: 'Most successful transitions involve simultaneous political and economic reform, and this is likely to be the case for Arab countries as well' (Amin et al., 2012, 2). The importance of the regional dimension for both understanding the Arab 
Spring and defining policies for democratic transitions is also underlined. ${ }^{4}$ The book's main message is that 'four main economic transitions are required':

First, more opportunities for young people need to be created. There are large intergenerational inequities in the distribution of the benefits of economic growth, in favor of a group of public sector employees, elites, and other rent seekers to the disadvantage of the large youth population in the region. (...)

Second, the Arab economies need to modernize their public sectors. There is still a strong demand for a developmental state role in Arab economies and a significant suspicion over the impact of liberal economic reforms that, under the old regimes, served to benefit only a few well-connected private groups. (...)

The third transition is in the private sector. Today, large elements of the private sector are seen as synonymous with corruption. Yet there is no sustainable economic model for the region that does not have the private sector playing a leading role. (...)

The fourth economic transition is in the approach to the rest of the world.

AMIN ET AL., 2012, 6-7, 9

These are all well-identified priorities, but mostly for pursuing in the longer term. Will weak governments engaged in transitioning to democracy have the time to pursue them? Is it not necessary to focus on some more immediate benefits? It is possible that, given that the book was the outcome of brainstorming that took place while the Spring was still unfolding, the urgency of stabilising the transition was not yet acutely felt.

Writing five years later, Ghanem (2016a) seems resigned to the inevitability of a neo-authoritarian parenthesis to put in place policies that, in due course, will facilitate transitioning to democracy. Thus he writes: '...can a country with no democratic tradition and with weak institutions become a well-functioning democracy and improve the lives of its citizens overnight? The answer is obviously no. Democratic transitions take years, even decades to succeed, and there are many twists and turns along the way. Moreover, they can be costly

4 '... there is a commonality to Arab history, language, and culture so it is reasonable to suppose that there is a regional identity that should not be ignored. Such a view is reinforced by the contagion demonstrated during the Arab Spring and the close links of people, ideas, news carried from country to country, and aspirations across the region' (Amin et al., 2012, 5). 
and require heavy human and economic sacrifices. Ask any Arab today if he or she feels that the region is better off than before the Arab Spring. What do you think the answer will be?' (Ghanem, 2016a, 2). He continues, telling us about a conversation with a Cairo taxi driver who is happy about President al-Sissi and proud of having overthrown two presidents before him (Mubarak and Morsi): he says that if al-Sissi does not perform, the people will get rid of him as well. Ghanem believes this has established some basic accountability of power; therefore, 'the Arab world appears to be moving toward more open and inclusive governance' (Ghanem, 2016a, 2). Clearly the author believes that the neo-authoritarian regime of al-Sissi may deliver where Mubarak failed: providing for more inclusive growth.

Ghanem's proposed cocktail of policies for achieving more inclusive growth is composed of four priorities: 'institutional reforms to improve implementation of policies and programs; reforms of the business environment, with a special emphasis on developing small and medium-sized enterprises (SMEs); rural development and support to lagging regions; and improving the quality of education'. None of these is objectionable, and clearly these are all priorities that can only be pursued in the longer run, as improvements will be slow to materialise. But none of these is new either: why were previous authoritarian regimes unable to pursue these priorities (they did in the 1950s and early 1960s, but progressively steered away and towards elite integration in regional oil rent circulation)? How can we expect that newly established authoritarian regimes, whose repressive inclination is only too evident, will behave differently to their predecessors?

The essays in this volume continue this debate, in many ways confirming the difficulty of proposing a cocktail of policies that will allow for rapid improvement in the living conditions of a majority of people and sustain consensus around the consolidation of democracy.

In Chapter 2, Samir Makdisi summarises the main conclusions of research on the historical entrenchment of Arab autocracies and of their subsequent unravelling in a few countries. He concludes that notwithstanding the unprecedented wave of popular revolt, 'the region's democratic prospects remain highly uncertain'. His key message concerning policies for the consolidation of democratic transitions is clear:

At the socio-economic level what would be required is the design and implementation of a broad based and what has come to be referred to as inclusive strategy, one that should create expectations that growth, expanding employment opportunities, and equity will play a major role in the transition to a new economy.

MAKDISI, this volume 
In Chapter 3, Adeel Malik revisits the rentier state theory and argues that its scope should be greatly enlarged to encompass numerous other sources of rent besides mineral extraction. He believes that rent formation and circulation is the key explanatory variable of unsatisfactory growth results and the stability of autocratic regimes in the region. He points specifically to the way in which nontariff barriers, bank lending and freedom of capital movements have been used to favour the formation and enrichment of elites close to the incumbent autocratic regimes. As he writes, 'it is easier to remove regime leaders than to eliminate the rentier structures that feed the associated elite coalitions', thus pointing to the difficulty of moving from one set of economic structures to another that would be more inclusive. This also points to the crucial importance of dismantling existing mechanisms for rent circulation and the very sources of internal rents if the door to more inclusive economic development is to be opened.

El-Katiri and Fattouh (Chapter 4) focus on energy subsidies as a very important form of rent circulation, documenting the extraordinary and crippling burden of these subsidies on the budgets of states that are not major exporters, such as Egypt, Tunisia and Yemen. For oil exporting countries the burden is 'virtual', in the sense that it translates into forfeited earnings rather than actual expenditure; but for all net importers of petroleum products the subsidies entail actual expenditure, which accounts, depending on the year and the average price of crude oil, for a very substantial share of government expenditure (in 2013-14 upward of 30 per cent in the case of Yemen, close to 20 per cent in the case of Egypt). It is clear that the opportunity cost of such outlays-that is to say, the possible alternative ways in which this money could be spent, is extremely significant.

El-Katiri and Fattouh underline that a reform of energy subsidies needs to be well prepared and compensated by some balancing measure in order to be successful. Thus subsidy reform succeeded in both Morocco and Jordan (which, not by chance, are the two 'democratising monarchies' in the region, notwithstanding limitations to their democratic progress), but failed in Yemen. Energy subsidy reform also succeeded in Egypt, but was implemented only after the restoration of authoritarianism and in the context of strong repressive measures. Finally, energy subsidy reform succeeded in Iran, whose case is especially interesting because the increase in energy prices was offset by cash payments to all citizens; $5^{\circ}$ per cent of the sums saved were allocated to cover these payments. The burden of energy subsidies in Iran was even higher than in the Arab countries concerned, but compensation with universal cash payments was undoubtedly a success. The programme later ran into difficulties, including due to international sanctions; but the experience demonstrated that a bold, if 'populist', move can send a signal of radical change—although in 
the case of the Ahmadinejad Administration the political context was certainly not one of democratisation.

In Chapter 5, Steffen Hertog argues strongly in favour of universal cash transfers. ${ }^{5} \mathrm{He}$ analyses the two main distribution mechanisms in use in the region - public sector employment and subsidies - and concludes that both have perverse effects. He stresses how 'apart from public employment and subsidies, Arab governments offer little by the way of social security policies' and traces the reasons for this to the priorities of authoritarian regimes. This creates a vicious circle whereby new redistribution policies cannot be initiated until the burden of excess employment and subsidies is lifted-yet abandoning the old policies without adequate compensation will be perceived as being profoundly unpopular. More modern social security policies are not created and put in place overnight, so a deterioration of living conditions may be unavoidable and politically unaffordable.

Hertog therefore clearly distinguishes between an agenda for the long run ('In the long run, Arab countries should build up conventional social security mechanisms such as means-tested income support, unemployment assistance, unemployment insurance, and active labour market policies such as retraining and job placement services') and one for the short run: 'direct, unconditional cash grants for all adult citizens. ${ }^{6}$ Hertog offers an articulate defence of the advantages of this solution in the MENA environment. He argues that such a policy would be beneficial for labour markets because it may be tailored to encourage private sector employment (excluding government employees from receiving the grants) and in this way equilibrate at least in part the attraction of public vs private sector jobs. It would also, I wish to add, constitute an incentive to remain in the home country, rather than adding to the relentless

5 The idea is found also in both Amin et al. (2012) and Ghanem (2016a). Amin et al. (2012, 89) write: 'A system that replaces the current energy and food subsidies with direct income transfers to the poor will be fairer and more efficient. However, Arab regimes have so far been unable to make such a change. (...) It remains to be seen whether the new governments resulting from the Arab Spring will be able to build the necessary consensus to bring about such a major policy change'. Ghanem (2016a, 33-34) writes: 'The idea of putting in place a social protection system based on targeted cash transfers has been studied in the Arab world for several years and could be quickly implemented. Experience from around the world indicates that such a system is much less expensive, more efficient, and fairer that price subsidies'.

6 The debate on the widening inequalities with regards to income and wealth taking place in practically all countries, whether attributed to globalisation or other causes, has greatly intensified in recent years. Various proposals for a 'citizens' income' have been put forward, especially in advanced countries. For a recent proposal focusing on the UK, see Painter and Thoung (2015). The approach is discussed also in Atkinson (2015, Chapter 8). 
stream of refugees and economic migrants that flows towards Europe-a good reason for European countries to provide financial and administrative support, at least in an initial phase, under the banner of facilitating democratic consolidation and easing immigration pressures.

There may be multiple ways of refining this approach and improve targeting. Restricting cash grants to the poorer strata is difficult because of the uncertainty of available income data and the potential for corruption and cheating; but it might be possible to focus a cash grant scheme on those age groups that encompass young entrants into the labour force ${ }^{7}$ - between 14 and 30 or 35. There might be multiple reasons for this approach: citizens in these age groups are the most politically active (and potentially attracted to extremist ideologies); in addition, one key component of the unstable political environment throughout the region is the unprecedented youth bulge, which-as highlighted by Fargues in Chapter 9 (and also by Hakimian, 2013b and Ghanem, 2016a) - characterises the Arab demography of the past and current decade.

Such a youth bulge is, on the one hand, a 'demographic blessing', because it temporarily reduces the ratio of dependents to the active population; but, on the other hand, it also constitutes an impossible challenge for the governments of the region, which are expected to create enough jobs to productively employ all new entrants. Migration has been a frequent response to this state of affairs among young entrants into the workforce that have found no opportunities at home. It is significant that the collapse of authoritarian regimes has led to an increased migration push that, as Fargues documents, has not exclusively been motivated by economic reasons. ${ }^{8}$ There is also some evidence that diasporas have fed a culture of revolt, either through 'political remittances' or by offering better opportunities for resistance in regions that experienced the highest migration rates (successful migrants offering potential support to those left behind). Fargues cites the example of positive correlation between regional rates of emigration in Tunisia and voting for Ennahda in the first election after the fall of Ben Ali. Political and economic mobilisation of diasporas offers a potential opportunity for governments aiming at consolidating the democratic transition. At the same time, migration also offers a safety valve for letting off the steam of political discontent (exit rather than voice); and the very high share of expatriates in the major Gulf oil producing countries is an objective

7 Child benefits are a frequently advocated component of redistribution policies: see e.g. Atkinson (2015, Chapter 8). Child poverty obviously deserves to be targeted, but in the regional context it may be feared that child benefits may end up supporting high fertility rates in countries where this is still a problem.

8 Christian and other religious minorities have felt threatened by political developments and have manifested an even stronger desire to migrate. 
obstacle to democratisation (Khalaf and Luciani, 2006; Luciani, Chapter 11 in this volume; Mehlum, Moene and Ostenstadt, 2016). This may also have the effect of weakening, at least temporarily, resistance to an authoritarian comeback - with people reverting to focusing on individual efforts at exit rather than collective voice.

Can migration become a tool for the consolidation of democracy rather than being just a phenomenon ignored in the sending countries, and resisted in the receiving ones? Could one think of policies to encourage return migration, in particular with incentives to repatriate know-how and establish new micro and small enterprises - a phenomenon that has played such an important role in the economic success of Turkey in the last three decades? Or could one establish policies to encourage remittances and investment in the country of origin? ${ }^{9}$ Could receiving countries tie conditions for access and progress in the direction of democracy together (and not just to protracted civil war: in other words, create an incentive for a positive, not just a negative, outcome of the transition)? ${ }^{10}$ Currently, Europe ends up paying the price for various catastrophes on humanitarian grounds, but does precious little to support the consolidation of democratic transitions.

Migration patterns are a sore point in relations with Europe, but also in inter-Arab economic relations, a point stressed by Luciani in Chapter 11. In the immediate aftermath of the first wave of increases in oil prices (1970-1985) some of the major oil exporters opened their doors to workers from other Arab countries quite wide: Iraq formally had a policy of encouraging migrants from the region, Yemenis could travel to Saudi Arabia without a visa, Kuwait hosted a large Palestinian population, a large number of Lebanese and Jordanians moved to the Gulf, and Libya took in a significant number of Egyptians and Tunisians. This pattern was brutally reversed in 1990, following the Iraqi invasion of Kuwait, because Palestine, Jordan and Yemen supported or did not condemn the Iraqi action, thus leading to mass expulsions from the GCC countries. Iraq suffered first from the impact of the war with Iran, and soon thereafter from the defeat that followed the invasion of Kuwait, so that it ceased being an attractive destination. Libya remained an important destination, especially for

Receiving European countries could establish facilities to provide credit to migrants wishing to return and set up businesses, or simply invest in their country of origin. Inadequate access to credit is a key obstacle to the development of small enterprises in MENA.

10 As I write these lines, Germany has announced that it is putting Tunisia, Algeria and Morocco on a list of 'safe countries', thus making immigration from these countries more difficult, while keeping the doors open to immigration from Syria and other countries in the throes of civil war (the Guardian, 2016). One can readily understand the logic, but democratic consolidation is thus not made any easier. 
Egyptian workers, until the country plunged into civil war. In the end, the role of inter-Arab migration as a potential equaliser of regional incomes deteriorated drastically. According to figures presented by Fargues (Chapter 9), the total number of Arab migrants in 2012 was just above 17 million, of which 8.6 million went to other Arab countries, 5.6 million to Europe and just 3 million to the rest of the world: ${ }^{11}$ inter-Arab migration therefore represents only 50 per cent of the total, and-in fact-probably less.

Agriculture is another key area with an influence on the outcome of democratic transitions, but is mostly neglected by newly elected governments and by external actors interested in their success. In Chapter 8, Eckart Woertz highlights how agriculture, while contributing relatively little to total GDP, consumes the bulk of scarce water resources and still employs a large share of the workforce in many countries in MENA (close to $5^{\circ}$ per cent in Sudan, South Sudan and Mauritania; 35 per cent in Yemen; 27 per cent in Oman; 23 per cent in Egypt and Morocco...). Insufficient attention has been paid by new democratic governments to living conditions in the countryside: in the context of policies of opening to international trade and investment, previous policies in support of the peasantry have been reversed, leading to continuing migration from rural to urban areas, and to a 'ruralisation of cities' - that is to say, an increase in the number of poor and marginalised inhabitants of the major urban areas. The transition towards capitalist agriculture has not led to significantly increased productivity and lower prices: 'People in many MENA countries including Egypt, Algeria and Morocco, spend more than a third of their disposable income on food'. Hence, food subsidies are difficult to eliminate and have great significance with regard to political legitimacy. This could be seen during the Arab Spring when Egyptian protesters strapped loaves of bread to their heads'. Relative to fuel subsidies, 'Food clearly commands a greater emotional appeal and-because of their self-targeting nature-the abolition of subsidies on staple foods would disproportionately hurt the poor'. But containing the cost of food for the urban dweller contrasts with improving the lot of people living off agriculture. The matter is made more difficult by widespread agricultural protectionism in industrial countries: the EU surplus in trade of agricultural products with MENA has been growing, for example. ${ }^{12}$

11 This includes Syrian refugees, which cluster in neighbouring countries. Civil wars and the ensuing wave of refugees swelled the ranks of regional migrants.

12 As discussed in Chapter 11, empirical research has demonstrated that the agreements concluded under the European Neighbourhood Policy have led to an increase in European exports but not of those of the Southern partners; agricultural protectionism is largely to blame. 
It is clear that improving the income and living conditions of the rural population in MENA would contribute to relieving migratory pressures, both internally towards urban areas that are overcrowded and incapable of accommodating new arrivals, and internationally — that is to say, towards Europe.

Eventually, however, whether policies to promote the significant potential of agriculture are successful or not, employment in the sector will need to decline both absolutely and as a share of the total. Inevitably, it is growth in industry and export-oriented services that will have to provide the jobs and opportunities required to accommodate the growing number of new entrants into the workforce. But services are vulnerable - we have already commented, in particular, on tourism in this respect. It is unrealistic to envision that the MENA region may simply bypass the industrial phase of development and directly pass from agriculture to services. Industry remains an essential component of any diversified economy, and so-called post-industrial societies are having growing misgivings about having too easily liquidated large parts of their industrial systems in the context of globalisation.

But when it comes to industry, MENA countries suffer from the weakness of their private sectors, in terms of both financial and industrial capabilities. 'While it is now widely accepted that private sector-led growth is necessary if structural unemployment in the region is to be addressed, state-led development remains a pervasive characteristic of the Arab world', writes Alissa Amico in Chapter 6 of this volume. '(...) question marks surround private sector's capacity to act as a locomotive of economic growth in the Arab world', and in practice the only alternative to continuing reliance on state-owned enterprises is privatisation, leading to foreign ownership. But multinational corporations will prioritise the elimination of excess employment, which is problematic in the short run for recently established democratic governments. Furthermore, large-scale sales of state-owned assets to foreign corporations would inevitably run against nationalist feelings and suspicions of corruption.

Improving the governance of state-owned enterprises and restoring them to profitability, so that they can contribute to the accumulation of capital and economic growth, is therefore an additional challenge for newly elected democratic governments. Where authoritarian incumbents failed in most cases, democrats must succeed: not an easy challenge in the face of popular expectations. In fact, employment in state-owned enterprises has rapidly increased in Tunisia, confirming the populist tendency to use economic assets as distributional rather than developmental tools.

A specific category of state-owned enterprises that deserves special attention and is in dire need of urgent reform is banks. State-owned banks dominate the banking sector in MENA and constitute a key pillar of rentierism and 
authoritarian control. Through control of the banking sector and selective, non-transparent and politically conditioned access to credit, state-owned banks facilitated the formation and survival of a non-performing class of crony capitalists to support the authoritarian regimes. The flip side of this coin has been the exclusion from access to credit of most small-scale and/or politically unconnected entrepreneurs, whose ability to contribute to growth and the creation of jobs has correspondingly been reduced (Diwan, 2016; Ghanem 2016a; Schiffbauer et al., 2015).

Restoring the role of banks and other financial institutions as intermediaries that enable entrepreneurs by facilitating their access to finance is an essential component of democratisation processes. Bassam Snaije argues in Chapter 7 that democratic institutions and governance are contextual with the development of financial markets, with special emphasis on the market for debt securities. He notes how the structure of financial markets in MENA differs significantly from that of Organisation for Economic Co-operation and Development (OECD) countries, inasmuch as it is dominated by bank credit, predominantly with short maturities; while the market for equity and debt securities is much less important. Furthermore, most banks, in particular those in countries outside the GCC, are either state-owned or controlled by families that are close to authoritarian power holders. Snaije believes that banking reform and enhancing the role of equity and debt securities markets should be a priority for democratising governments, in order to allow new participants to access finance, foster growth and promote agreements of trust that are not based on personal acquaintance and proximity to power.

Faced with the difficulty of formulating economic policies that will help consolidate a democratic transition, is the solution a return to 'modern autocracy' in the hope that it may eventually evolve in a genuinely democratic direction? This is where the case of Egypt is crucially important: not only is Egypt the most populous and geographically and politically central Arab country, it is also the one in which the credibility of the potential 'authoritarian route to democracy' is the subject of experiment. After the collapse of the democratically elected Morsi Administration, largely due to its utter inability to govern a collapsing economy and manage a transparent and inclusive democratisation process, the Army is back in power under Marshal al-Sisi: will he deliver the economic miracle that Egypt needs? In Chapter 10, Robert Springborg expresses his profound scepticism in this respect. The conclusion of his detailed analysis of Egypt's economic ills and the current regime's approach to them is stark: '...al-Sisi's Egypt is doubling down on what preceding regimes in that country and those elsewhere in the world have demonstrated to be a failed strategy for economic development'. Indeed, Egypt may eventually become 
another basket case, like Yemen or the Sudan. Repression will then maintain political stability only temporarily.

In the final chapter in this volume, Giacomo Luciani focuses on the regional environment of the Arab Spring and Arab economies. He argues that the Spring was indeed a regional rather than country-specific phenomenon, and all Arab countries are-in one way or another-involved in a regional civil war, although that war is currently only being actively fought in four of them (Iraq, Libya, Syria and Yemen). The outcome of the regional civil war will eventually determine the political future of all MENA countries. Regional economic integration has been prevented by multiple political conflicts, yet is essential for the success of the very economic policies that might consolidate democratic transitions - assuming that the outcome of the Arab civil war will point in that direction.

It is clear from the above discussion and from the remainder of this volume that democratic transitions face a serious problem inasmuch as they can expect to face deteriorating economic conditions while expectations of rapid improvement among a majority of the people, especially the poorer strata, are high. Our research has pointed to some initiatives that may be undertaken relatively quickly and give a strong signal in the direction of greater inclusion. It remains difficult to move rapidly and obtain visible results quickly, but newly installed democratic governments should be bold. ${ }^{13}$

The abolition of fuel subsidies that only benefit the middle classes and the rich is a case in point: fiscal space gained with this measure might be used, as suggested by Hertog, for a programme of unconditional cash transfers to either all citizens or some easily verified categories; in any case avoiding complex bureaucracy that would invite corruption. This would benefit citizens that presently derive minimal or no advantage from fuel subsidies.

The merits of a large enough devaluation should be carefully considered. The drawbacks of an overvalued exchange rate are frequently mentioned as an obstacle to growth as is the fact that such an obstacle may hurt democratic

13 '... it would be a mistake not to take the opportunity afforded by the major political transition to make significant reforms to the economic structure in each country. Politicians often have a short window of opportunity in which to succeed or fail-what was called the period of "extraordinary politics" when reforms can be accomplished with an ease that will later vanish'. (Amin et al., 2012, 13). 
transitions. ${ }^{14}$ Devaluations tend to damage all those whose consumption basket includes a significant component of imported goods - which is normally not the case for the poorer segments and the marginalised. Devaluation is likely to shift demand in favour of domestic agricultural products, and in this way shift income from cities to the countryside. It also improves the competitiveness of all manufactured exports, and of services such as tourism. If government income is at least in part linked to revenue from the export of raw materials, whose price is fixed internationally in dollars, devaluation also creates further fiscal space for the government. Conversely, devaluation is also an advantage to all citizens that have wealth or income denominated in foreign currencies: migrants' remittances may be encouraged and become more important, but crony capitalists who have piled up wealth in foreign accounts would also benefit. Finally, the government may gain or lose depending on whether public debt is denominated in the national or some foreign currency. Thus the net impact of using the exchange rate tool is difficult to predict a priori, but a case can be made that bold use of this tool in connection with political transition might be beneficial.

Reform of the banking sector can also be pursued relatively quickly. Banks should be invited to wipe their balance sheet clean of bad loans. Connivance between banks and crony capitalists must be broken as a first step in the direction of the restructuring of the banking sector and the reopening of credit opportunities to new, especially small-scale, entrepreneurs. Restructuring banks, changing their management especially by tapping the frequently considerable pool of national talent available in the diaspora, forcing recapitalisation when necessary and isolating non-performing debts in separate 'bad bank' structures would go a long way to turning a page in the political economy of democratising countries.

Thus, short-term policy tools are available and should be used boldly, while at the same time aiming at the longer-term objectives that the literature has very clearly identified. Yet, it will remain difficult to succeed unless the regional environment also evolves in the right direction. The dichotomy between rich and poor states in the region must be overcome through greater openness, and encouragement given to regional movements of capital and labour and

14 'The exchange rate in many countries is out of equilibrium, supported either by capital controls or by official reserve sales. Unlike other cases of major economic transition, Arab economies have not witnessed strong currency depreciations as yet. Without more exchange rate adjustments, however, the long-term fundamental reforms to encourage the private sector and increasingly open the economy to the rest of the world will not be successful'. (Amin et al., 2012, 83-84). 
effective market integration. A degree of political convergence is a prerequisite for this, and democratic transitions are unlikely to succeed if they have to swim against the tide of regional authoritarianism.

\section{References}

Acemoglu, D., S. Naidu, P. Restrepo and J.A. Robinson (2014) Democracy Does Cause Growth, NBER Working Paper No. 20004 (Massachusetts: National Bureau of Economic Research) DOI: 10.3386/w20004.

Achcar, G. (2013) The People Want-a Radical Exploration of the Arab Uprising (Berkeley: University of California Press), 328 pages.

Alvaredo, F. and T. Piketty (2014) Measuring Top Incomes and Inequality in the Middle East: Data Limitations and Illustration with the Case of Egypt, Working Paper Series 832 (Cairo: Economic Research Forum), http://piketty.pse.ens.fr/files/Alvaredo Piketty2014ERF.pdf (accessed on 17 March 2016).

Amin, M., R. Assaad, N. al-Baharna, K. Dervis, R.M. Desai, N.S. Dhillon, A. Galal, Hafez Ghanem, C. Graham, and D. Kaufmann (2012) After the Spring:Economic Transitions in the Arab World (Oxford, Oxford University Press).

Atkinson, A.B. (2015) Inequality —What can be done? (Cambridge (Massachusetts): Harvard University Press).

Azmeh, S. (2014) The Uprising of the Marginalised - a Socio-Economic Perspective of the Syrian Uprising, LSE Middle East Centre Paper Series 6, November (London: LSE Middle East Centre) http://www.lse.ac.uk/middleEastCentre/publications/PaperSeries/UprisingoftheMarginalised.pdf (accessed on 31 March 2016).

Beinin, J. (2016) Political Economy and Social Movement Theory Perspectives on the Tunisian and Egyptian Popular Uprisings of 2011, LSE Middle East Centre Paper Series 14 January (London: LSE Middle East Centre) http://eprints.lse.ac.uk/65291/ (accessed on 1 April 2016).

Devarajan S. and L. Mottaghi (2014) 'Predictions, Perceptions and Economic RealityChallenges of the seven Middle East and North Africa Countries described in 14 Charts' MENA Quarterly Economic Brief, August (Washington, D.C.: World Bank) http://elibrary.worldbank.org/doi/abs/10.1596/978-1-4648-0407-6.

Diwan, I. (2016) 'Economic Growth After the Arab Spring', Project Syndicate, March 4, https://www.project-syndicate.org/commentary/arab-spring-countries-economic -growth-by-ishac-diwan-2016-03 (accessed on 1 April 2016).

Ghanem, H. (2016a) The Arab Spring Five Years Later-Toward Greater Inclusiveness (Washington D.C.: Brookings Institution Press).

Ghanem, H. (ed.) (2016b) The Arab Spring Five Years Later-Case Inclusiveness (Washington D.C.: Brookings Institution Press). 
Guardian (The) (2016) 'Germany tightens refugee policy as Finland joins Sweden in deportations', January 29, http://www.theguardian.com/world/2016/jan/29/ germany-tightens-borders-as-finland-joins-sweden-in-deporting-refugees (accessed on 5 April 2016).

Hakimian, H. (ed.) (2013a) Inclusive Growth in MENA: Employment and Poverty Dimensions in a Comparative Context, Femise Research Programme Research No. FEM 35, 16 June (London: Middle East Institute and Economics Department, soAs) http://eprints.soas.ac.uk/17319/3/Inclusive\%2oGrowth\%2oin\%2oMENA\%20-\%20 Employment\%20and\%2oPoverty\%2oDimensions\%2oin\%2oa\%2oComparative\%20Context\%20\%28FEM3516_June\%202013\%29.pdf (accessed on 1 April 2016).

Hakimian, H. (2013b) 'The Search for Inclusive Growth in North Africa: A Comparative Approach' Economic Brief (Abidjan: African Development Bank) http://www .afdb.org/fileadmin/uploads/afdb/Documents/Publications/Economic_Brief_ -_The_Search_for_Inclusive_Growth_in_North_Africa-_A_Comparative_Approach .pdf (accessed on 1 April 2016).

Hanieh, A. (2013) Lineages of Revolt-Issues of Contemporary Capitalism in the Middle East (Chicago : Haymarket Books).

Kamrava, M. ed. (2014) Beyond the Arab Spring - The Evolving Ruling Bargain in the Middle East (London: Hurst).

Khalaf, A. and G. Luciani (eds.) (2006) Constitutional Reform and Political Participation in the Gulf, (Dubai: Gulf Research Centre).

Luciani, G. (2016) On the Economic Causes of the Arab Spring and its Possible Developments in K. Selvik and B.O. Utvik (eds) Oil States in the New Middle EastUprisings and Stability (Abingdon and New York: Routledge).

Mehlum, M., K. Moene and G. Ostenstadt (2016) 'Guest workers as a barrier to democratization in oil-rich countries' in K. Selvik and B.O. Utvik (eds) Oil States in the New Middle East-Uprisings and Stability (Abingdon and New York: Routledge).

Nugent, J.B., (2012) Detecting Corruption and Evaluating Programs to Control It: Some Lessons for MENA Working Paper $\mathrm{n}^{\circ} 738$ (Giza, Egypt: Economic Research Forum) http://erf.org.eg/publications/detecting-corruption-evaluating-programs-control -lessons-mena/ (accessed on 1 April 2016).

Painter, A. and C. Thoung (2015) Creative citizen, creative state: the principled and pragmatic case for a Universal Basic Income (London: RSA), available on https://www .thersa.org/.

Piketty, T. (2013) Le capital au XXIe siècle, (Paris: Seuil).

Schiffbauer, M, A. Sy, S. Hussain, H. Sahnoun, P. Keefer, I. Diwan, D. Al-Kadi, D. Doemeland, and B. Rijkers (2015) Jobs or Privileges: Unleashing the Employment Potentialof theMiddleEastandNorthAfrica,MENADevelopmentReport(Washington, D.C.: World Bank) http://documents.worldbank.org/curated/en/2014/o6/19794535/ jobs-or-privileges-unleashing-employment-potential-middle-east-north-africa (accessed on 31 March 2016). 
Schuhmacher, T. (2016) Back to the Future: The 'New' ENP towards the Southern Neighbourhood and the End of Ambition, СЕ Ров Policy Brief No.1/16, January (Bruges: College of Europe) https://www.coleurope.eu/system/files_force/research-paper/ schumacher_cepob_1-16.pdf?download=1 (accessed on 1 April 2016).

Selvik, K. and B.O. Utvik (eds.) (2016) Oil States in the New Middle East-Uprisings and Stability (Abingdon and New York: Routledge).

Springborg, R. (2016) 'Globalization and Its Discontents in the MENA' Middle East Policy, v. XXIII, no. 2 (Summer 2016). http://www.mepc.org/journal/middle-east -policy-archives/globalization-and-its-discontents-mena (accessed on 23 June 2016).

Verme, P., B. Milanovic, S. Al-Shawarby, S. El Tawila, M. Gadallah, A. El-Majeed and A. Enas (2014) Inside Inequality in the Arab Republic of Egypt: Facts and Perceptions across People, Time and Space, World Bank Studies (Washington, D.C.: World Bank) http://hdl.handle.net/10986/17583.

World Bank (2014) The Unfinished Revolution: Bringing Opportunity, Good Jobs And Greater Wealth To All Tunisians, Synthesis Development Policy Review, May (Washington, D.C.: World Bank). http://www.worldbank.org/content/dam/Worldbank/ document/MNA/tunisia_report/tunisia_report_the_unfinished_revolution_eng_ synthesis.pdf (accessed on 4 April 2016).

World Bank (2016) The Economic Effects of War and Peace MENA Quarterly Economic Brief, January (Washington, D.C.: World Bank) http://www.worldbank.org/en/ region/mena/publication/mena-quarterly-economic-brief-january-2016 (accessed on 4 April 2016). 